\title{
Epilogue - Towards a Reconstitution
}

In October 2019, a social uprising in Chile marked the beginning of the deepest crisis of the country's institutional and political order in decades. Due to the raise of the subway tariffs of thirty Chilean pesos (approximately $€ 0,03$ ), social protests from diverse social, political, and cultural sectors started to mobilise against the political establishment and the neoliberal foundation of their society; they claimed that it is not about thirty pesos, but rather about thirty years of neoliberalism.

In connecting their protest to the institutionalisation of neoliberalism, the nationwide uprising has succeeded in doing what was not possible during thirty years of postdictatorial democracy: to shake up the neoliberal hegemony. This includes demands for the abolition of the privatised pension and health care systems; a reform of the education system; and an end to the high cost of electricity and public transportation, the privatised water supply, land concentration, patriarchal conservativism, and an ecologically disastrous extractivism (Liebermann and Garbe 2020).

While diverse social sectors of these protests explained their resistance with thirty years of neoliberal democracy, a highly active Mapuche youth in the country's urban centres ('Mapurbe'), Mapuche communities, and organisations rather framed the protest within 300 years of coloniality. In that context, the social uprising in Chile not only lays bare the crisis of neoliberalism in Latin America, but can rather be addressed as a phenomenon of the "deep crisis of the global coloniality of power" (Quijano 2014d, 852; my translation). This is because what has become visible since the beginning of the social uprising in Chile "has been already happening in Wallmapu for a long time ago, but now it is spreading throughout all territories" (Brito 2021, 86; my translation). This concerns, on the one side, the state repression and systematic human rights violations on a national scale since October 2019 and, on the 
other, the formation of alternative communal assemblages beyond neoliberal capitalism and coloniality.

The preliminary success of this protest cycle is the election of a constitutional assembly in May 2021 with an overwhelming majority for left-leaning and left-wing candidates. While a new constitution is necessary for change to continue, the path to it also holds dangers of political appropriation and institutional pitfalls (Liebermann and Garbe 2020). Nevertheless, the social, cultural, and political transformation that has gained momentum since October 2019 already goes well beyond the institutional constraints of a constitutional reform, as the analysis of activists Alondra Castillo and Javiera Manzi from the Chilean Coordinadora Feminista $8 M$ invite us to consider: "We think that a much deeper and more radical constituent sense is at stake; that we are constituting ourselves as a movement, as peoples; that we are reconstituting ourselves in the possibility of politicizing ourselves, of imagining another life" (Castillo and Manzi 2021, 31; my translation)

This inspiring statement made me think about possible connections between the idea of a 'reconstitution' and my argument for a weaving sense of solidarity. This is why I want to conclude by asking: ${ }^{1}$ a) what consequences can be drawn from the latest developments in Chile for this research? And b) how can a perspective that centres the agency and autonomy of the Mapuche and raises awareness about the perpetuated violence in Wallmapu contribute to understanding what is going on in the whole country? In other words, how can decolonial perspectives on solidarity of and with the Mapuche also shed light on the limitations and possibilities of a social, political, and cultural reconstitution in Chile?

The brutal repression against the social uprising since the beginning of the protests caused national and international outrage. Within just a bit more than one month more than 12,000 people were hospitalised, approximately 2,000 had gunshot wounds, almost 350 suffered severe eye injuries, and countless protesters reported sexual and other forms of abuses by the security forces (Gaudichaud 2021). Also, several protesters that were fatally injured or killed in the first weeks of the repression must be added to the list of victims (Tinta Limón 2021, 9-12).

1 Some of these explorative thoughts have been developed and presented together with Julia Liebermann at the $36^{\text {th }}$ annual convention of the Austrian Latin American Studies Association in May 2021. 
These bitter numbers are a reminder of the darkest years of the Chilean dictatorship and images of the military police patrolling the streets of Santiago de Chile during the curfew caused international and domestic outrage against the government's repressive response. While these weeks brought back traumatising memories for a whole generation of Chileans, the repression and human rights violations never really ceased in Wallmapu. In other words, "everything we have seen since October [2019] in the centre of the cities (militarization, repression, assassinations, etc.) has had the Araucanía region as its laboratory, from 1997 to the present" (Zapata 2021, 146; my translation). Hereby, Claudia Zapata refers to the events that took place in 1997 in the small town of Lumaco in the Chilean South, where Mapuche communities protested the logging company Forestal Arauco. Their protest was followed by a wave of persecution, repression, and criminalisation, unprecedented during democracy. This is why the events in Lumaco from 1997 can be interpreted as a point of inflection towards a new conflict dynamic between private (neo-)extractivist companies, the Chilean state, and Mapuche organisations and communities. The only difference, following Claudia Zapata, is that this conflict dynamic now has been extended towards the urban centres and the mostly non-Indigenous populations.

At the same time, it is not only the repression that has expanded from Wallmapu to the Chilean (urban) territory-so has the potential for resistance and transformation. This is because of the important contribution young Mapuche, socialised in urban Chile, made to the social uprising. In that way, the current dynamic has a decolonising direction as it reverses the colonising process from the nineteenth century; now "there is a conquest of the 'barbarity' (the marginalised of the city and of the [neoliberal] model) over the enlightened city," as Fernando Pairican ironically and sharply analyses (2021, 178; my translation). Not only were statues of former colonisers of Wallmapu decapitated during the protests, but also the wenufoye instead of the Chilean flag became the most visible icon of the social uprising.

But beyond the representational level, concrete demands and practices that have their origin in Wallmapu were also transferred to the Chilean territory. One example is territorial recuperation, which has been practiced by Mapuche organisations and communities continuously since the 1960 up to the present day. This refers to the occupation of certain small portions of land in Wallmapu by claiming their ancestral right to this territory, often in reference to the titulos de merced. The most famous expression of the transference of such territorial recuperations is the occupation of Plaza Italia in Santiago 
de Chile, renamed into Plaza Dignidad (Square of Dignity) by the protesters. Another example of how political demands from the Mapuche movement reverberate within the social uprising is the call to 'relaunch' or 're-establish' (refundar) the Chilean military police-the Carabineros-by a broad alliance of social movements, political parties, and unions in early 2021 (NODAL 2021). The demilitarisation of Wallmapu has already been a central demand of Mapuche organisations and communities, also within transnational advocacy, for many years. The latest steps towards territorial autonomy taken, for example, by the community of Temucuicui show how Mapuche organisations and communities predate demands articulated within the nationwide uprising. Not only did they implement measures to protect their community from the COVID-19 pandemic by controlling access to their territory, but they also announced the foundation of their own community police in early 2021 (Stuardo 2021). Putting these experiences in a dialogue with the nationwide demands as well as with global developments regarding police abolition and defunding, most prominently put forward within the Black Lives Matter movement in the USA, might be a promising direction of further research.

Despite the overwhelming majority who voted in favour of a constitutional convention in a plebiscite in October 2020 and the election of a vast number of progressive and left-oriented candidates into the convention in May 2021, the question remains open of whether the constitutional reform can assure a deep political and economic transformation. A close but brief look at the relations of Mapuche communities, organisations, and leaders with the process towards a constitutional reform is therefore insightful for deciphering some of its pitfalls and potentials.

To begin with, a total number of seventeen seats in the constitutional convention were reserved for the ten Indigenous nations living in Chile, seven of them for the Mapuche. What is remarkable is that all seats reserved for the Mapuche were won by independent and mostly self-funded candidates associated with autonomist and territorial recuperation movements. Particularly, the successful campaigns by machi Francisca Linconao and the Mapuche lawyer Natividad Llanquileo, winning first and second place, stand out (Equipo de Trabajo por Derechos Colectivos 2021).

The road to the election of the constitutional convention was nevertheless paved by at least three controversies regarding the participation of the Mapuche candidates. The first concerns that fact that the law regulating the process towards a constitutional reform, the Acuerdo por la paz social y la nueva Constitución (Agreement for social peace and a new constitution), approved 
in November 2019, did not entail a previous, free, and informed consultation of the Indigenous population as demanded within the ILO 169 convention. They were instead, again, included through a top-down approach. Second, the number of reserved seats for the Indigenous population does not correspond with their percentage of the national population. According to the national census, there should have been twenty-four seats, which is why it is safe to assume that the distribution of those reserved seats is "not a question of mathematics, it's racism" (Tricot 2020; my translation). Finally, the last controversy refers to the fact that only those could vote for an Indigenous candidate who were officially and previously registered as an Indigenous person at the CONADI or the electoral offices. This excluded a considerable number of Indigenous people with a more autonomist vision, who refuse to be subjected to such registration practices.

A preliminary analysis of the election results for a constitutional convention must not only recognise the exceptional efforts of the campaigns by Mapuche candidates from autonomist sectors of the society, but also the prominence of Mapuche women candidates. Besides the already mentioned machi Francisca Linconao and Natividad Llanquileo, the successful campaign of the Mapuche scholar Elisa Loncón and the candidacy of machi Francisca Linconao's former spokeswoman, Ingrid Conejeros, stand out. Not only do many of the Mapuche candidates come from autonomist sectors of their society, but some were themselves victims of state violence, repression, and persecution. What is more, in a trawvn in February 2021 twelve Mapuche candidates for the constitutional convention explicitly named the "reconstruction of the Mapuche nation, Wallmapu" as their goal (Koyagtun Koz-Koz 2021; my translation). But here is the catch: contrary to the autonomist stance of these candidates, a representative survey from early 2020 shows that "the option of the Indigenous Peoples being able to form an independent state from Chile does not attract much support" (CIIR 2020, 41) neither amongst Indigenous nor non-Indigenous participants.

What conclusion can be drawn from what appears to be a contradiction between the autonomist demands of political Mapuche leaders and the lack of broad social support for autonomy? At first sight, the gap between the autonomist movement and the broader social, Indigenous base throughout the country seems to grow bigger within the constitutional process-not only between some prominent figures and their society, but also between the former and some autonomist communities, who disapprove of their participation within the constitutional process altogether. 
In contrast, I want to conclude with a different, more promising interpretation. The current dynamic bears the potential to canalise experiences of survival strategies of the Mapuche within the Chilean state through a reconstitution from below. The constant labour of reassembling their sociocultural tissue despite state persecution and economic disadvantages is what finally recomposes a Mapuche society and at the same time weaves it into the dominant Chilean society by creolising and transculturalising it. In reference to the centrifugal and centripetal force of their cultural politics of autonomy, analysed in chapter four, the current dynamic thus also shows how "the Mapuche society began to develop strategies of accumulating forces, first to survive, then to infiltrate" (Lincopi 2021; my translation). The electoral victories of autonomist Mapuche candidates seem to introduce the second step. On a sociocultural level, the Mapuche resistance of the last decades, gaining prominence within the social uprising, has already won further ground: for example, data from a recent study shows that self-identification as Indigenous jumped from 12.8 percent in 2017 (Instituto Nacional de Estadísticas 2017, 16) to 28 percent in 2020 (CIIR 2020, 41). In the same study, an overwhelming number ( 92 percent) support an education in Indigenous languages in the country for both Indigenous and non-Indigenous people alike (Ibid.). While these numbers might seem surprising for some, as detailed with the strategy of mapuchising, the Mapuche "have always imagined another country with cultural diversity, etc." (Zapata 2021, 148; my translation). In that sense, "what is in crisis is a political culture and a power structure for which the Indigenous movements [in Chile] have been preparing themselves for decades" (Lincopi 2021; my translation).

This means that the political resistance and sociocultural reconstitution led by Mapuche organisations and communities are now enabling transformations within the political institutions of the Chilean nation. The seeds that have been planted for decades are now being harvested within nationwide debates about intercultural rights, self-determination, plurinationality (Pairican $2021,174)$, and police reform, as well as within the latest election results. Together with the discussed contradictions of Mapuche candidates participating in the constitutional reform, a horizon for enabling a deep, sustainable, and decolonising reconstitution of the Chilean society also becomes visible. Inspired by the practice of territorial recuperations of Mapuche communities in the 1960 s and '70s, today "pushing the fence forward" seems more possible than ever (Millabur in Pairican 2021, 174; my translation). Beyond that fence, there is a decolonial future that waits to be woven. 